\title{
Hubungan Kebiasaan Merokok, Menyirih dan Lama Bekerja dengan Penurunan Kadar Cholinesterase pada Petani di Desa Gajah Pokki Kabupaten Simalungun
}

\author{
Anneta Margaretta Tambunan ${ }^{1 *}$, Habsah Ritonga ${ }^{1}$, Nisa Krisnawati Pasaribu ${ }^{1}$ \\ ${ }^{1}$ Universitas Prima Indonesia kampus 2 Jl. Sekip Simpang Sei Kambing Medan \\ 20113, Indonesia \\ Email : margarettatambunan266@yahoo.com
}

\begin{abstract}
ABSTRAK
Pemaparan pestisida pada petani dapat menyebabkan penurunan aktivitas cholinesterase. Adapun penyebab terjadinya penurunan aktivitas kadar cholinesterase yaitu akibat masuknya zat kimia pestisida ke dalam tubuh melalui oral. Penelitian ini merupakan penelitian kuantitatif dengan desain crosssectional. Populasi penelitian ini adalah petani yang tinggal di Gajah Pokki sebanyak 220 petani. Sampel pada penelitian ini sebanyak 20 petani dalam memakai pestisida dengan kriteria sampel sebagai berikut : petani yang dengan masa kerja $>10$ tahun, petani yang bersedia diambil sampel darahnya. Teknik atau pengambilan sampel yang digunakan dalam penelitian ini adalah purposive sampling. Hasil penelitian ini diuji secara statistik dengan menggunakan uji chi square dengan menganalisa tabel menggunakan uji Fisher Exact dengan tingkat kepercayaan 95\%. Hasil penelitian menunjukkan bahwa tidak adanya hubungan merokok , tidak ada hubungan kebiasaan menyirih dan tidak ada hubungan lama bekerja dengan penurunan kadar cholinesterase, dari hasil yang diperoleh disarankan adanya kerjasama pemerintah, institusi kesehatan dan institusi pendidikan dalam memberikan penyuluhan kepada petani untuk mengingat bahaya racun zat kimia pestisida dalam jangka panjang yang sangat berpengaruh terhadap kesehatan terutama penurunan kadar cholinesterase pada petani.
\end{abstract}

Kata kunci : Kadar Cholinesterase, Kebiasaan Merokok, Menyirih, Lama Bekerja

\section{Corelation Between between smoking, betel and Long Work with Decreased Cholinesterase Levels in Farmers in the Gajah Pokki Village Simalungun Regency}

\begin{abstract}
Pesticide exposure to farmers can cause a decrease in the activity of a decrease in cholinesterase activity, which is due to the entry of pesticide chemicals into the body, especially through the oral. This research is a quantitative study with crosssectional design. The population of this study were 220 farmers who lived in Gajah Pokki. The sample in this study were 20 farmers using pesticides with sample criteria is farmers with a working period of $>10$ years, farmers who are willing to take blood samples. The technique or sampling used in this study is purposive sampling the results of this study were statistically tested using the Chi square test with a confidence level of $95 \%$. The results showed that there was a relationship no smoking corelation, no betel corelation, and no long standing corelation with a decrease in cholinesterase levels. from the results suggested that cooperation between government, health institutions and educational institutions in providing counseling to farmers to given the chemical dangers of long-term pesticides which greatly affect health, especially the decrease in cholinesterase levels in farmers.
\end{abstract}

Key words : Decreasing Cholinesterase Levels, Smoking, Betel, Working Long. 


\section{Pendahuluan}

Bahan aktif yang terkandung pada pestisida tergabung dalam struktur senyawa dan sifat kimiawi yang sama meskipun toksiloginya sangat berbeda. Semua kelompok organofosfat memiliki racun saraf yang bekerja untuk menghambat aktivitas enzim cholinesterase.

Pemaparan pestisida pada petani dapat menyebabkan penurunan aktivitas cholinesterase. Adapun penyebab terjadinya penurunan aktivitas kadar cholinetrase yaitu kelengkapan alat pelindung diri (APD) yang tidak digunakan, pengelolaan pestisida yang tidak sesuai, lama bekerja dan jumlah pestisida yang tidak tepat. Sehingga petani dapat menderita keracunan dan membahayakan kesehatan petani. Hal ini dapat diketahui dari hasil penelitian Istianah (2015).

Menurut WHO menyatakan bahwa keracunan pestisida secara langsung maupun secara tidak langsung adalah suatu masalah yang serius terhadap pertanian di Negara miskin dan berkembang. Diperkirakan sekitar 250.000 korban jiwa terjadi karena keracunan pestisida di setiap tahunnya.

Kabupaten Simalungun merupakan salah satu sentral pertanian bagi Sumatera Utara terutama tanaman hortikural, jenis sayur-sayuran dan buah-buahan. Pertanian merupakan tempat mata pencaharian terbanyak bagi masyarakat yang berada di Simalungun.

Hasil survey awal yang dilakukan di Desa Gajah Pokki pada tanggal 05-10 Oktober 2018 kepada 20 petani, diantaranya yang sudah lama bekerja lebih dari 10 tahun, kemudian petani tidak mengikuti prosedur pemakaian pestisida. Kebanyakan dari petani menggunakan dosis yang berlebihan dengan menambah satu sendok atau lebih dari dosis yang telah ditentukan. Pada saat petani melakukan kegiatan pekerjaan kebanyakan petani sering menkonsumsi sirih dan merokok, sehingga diduga terjadi paparan pestisida secara oral.

Pemeriksaan awal yang dilakukan pada tanggal 24 April 2019 diperoleh hasil bahwa terjadi penurunan kadar cholinesterase pada 2 dari 3 sampel darah petani yang diperiksa di laboratorium Gatot Subroto Medan.

Berdasarkan latar belakang diatas, maka tim peneliti ingin meneliti tentang "Hubungan Kebiasaan Merokok, Menyirih dan Lama Bekerja dengan Penurunan Kadar Cholinesterase pada Petani di Desa Gajah Pokki Kabupaten Simalungun".

\section{Metode Penelitian}

Penelitian ini merupakan penelitian kuantitatif dengan desain cross-sectional, dengan jumlah sampel sebesar 20 orang diambil secara purposive sampling, dengan kriteria responden: sampel petani yang mencampur pestisida dan menyemprot tanaman, petani dengan masa kerja $>10$ tahun, dan petani yang bersedia diambil sampel darahnya. Penelitian ini dilaksanakan dari bulan Oktober 2018 - Agustus 2019.

Pengumpulan data dalam diperoleh melalui pemeriksaan langsung sampel darah untuk mengetahui kadar cholinesterase yang dilakukan di laboratorium Gatot Subroto Medan dan menggunakan kuesioner serta observasi lapangan. Analisis statistik dilakukan dengan menggunakan uji chi-square serta menganalisis tabel menggunakan uji fisher Exact dengan tingkat kepercayaan $95 \%$. 
Hasil

Distribusi Responden

Tabel 1 Distribusi Frekuensi Responden

\begin{tabular}{llcc}
\hline \multicolumn{1}{c}{ Karakteristik } & \multicolumn{1}{c}{ Kategori } & Jumlah $(\mathbf{N})$ & Persentase (\%) \\
\hline \multirow{3}{*}{ Jenis Kelamin } & Laki-laki & 11 & $55 \%$ \\
& Perempuan & 9 & $45 \%$ \\
\multirow{3}{*}{ Usia } & $17-25$ & 1 & $50 \%$ \\
& $26-35$ & 8 & $40 \%$ \\
& $36-45$ & 8 & $40 \%$ \\
& $46-55$ & 2 & $10 \%$ \\
Pendidikan Terakhir & $>65$ & 1 & $5 \%$ \\
& SMP & 3 & $15 \%$ \\
& SMA & 14 & $70 \%$ \\
& Sarjana/ PT & 3 & $15 \%$ \\
\hline
\end{tabular}

Berdasarkan tabel 1 distribusi frekuensi karakteristik responden dapat diketahui bahwa mayoritas responden adalah laki-laki sebanyak 11 orang (55\%) umur 26-35 sama banyaknya 36-45 tahun sebanyak 8 orang (40\%), dan pendidikan responden mayoritas tamatan SMA sebanyak 14 orang $(70 \%)$.

Table 2 Analisis Univariat Hubungan Kebiasaan Merokok, Konsumsi Sirih/suntil dan Lama Bekerja dengan Penurunan Kadar Cholinesterase pada Petani di Desa Gajah Pokki Kabupaten Simalungun

\begin{tabular}{llcc}
\hline Variabel Independen & Kategori & Jumlah $(\mathbf{N})$ & Persentase (\%) \\
\hline \multirow{2}{*}{ Kebiasaan merokok } & Tidak & 5 & $25 \%$ \\
\cline { 2 - 4 } & Ya & 15 & $75 \%$ \\
\hline \multirow{2}{*}{ Menyirih } & Tidak & 10 & $50 \%$ \\
\cline { 2 - 4 } & Ya & 10 & $50 \%$ \\
\multirow{2}{*}{ Lama Kerja } & $<10$ tahun & 4 & $20 \%$ \\
\cline { 2 - 4 } & $>10$ tahun & 16 & $80 \%$ \\
\hline
\end{tabular}

Berdasarkan tabel 2 variabel independen dapat diketahui bahwa responden dengan kebiasaan merokok lebih banyak yang merokok yaitu 15 orang (75\%), dan responden yang menyirih sama dengan yang tidak menyirih sebanyak 10 orang $(50 \%)$, kemudian lama bekerja $\geq 10$ tahun sebanyak 16 orang $(80 \%)$.

\begin{tabular}{llcc}
\hline \multicolumn{1}{c}{ Variabel Dependen } & Kategori & Jumlah $(\mathbf{N})$ & Persentase $(\%)$ \\
\hline \multirow{2}{*}{ Cholinesterase } & Tidak normal & 7 & $35 \%$ \\
\cline { 2 - 4 } & Normal & 13 & $65 \%$ \\
\hline
\end{tabular}


Berdasarkan variabel dependen diatas dapat diketahui bahwa responden yang tidak normal terhadap cholinesterase lebih banyak yaitu 7 orang (35\%), dibandingkan yang normal terhadap cholinesterase sebanyak yaitu 13 orang $(65 \%)$.

\section{Analisis Bivariat}

Tabel 3 Hubungan Kebiasaan Merokok dengan Penurunan Kadar Cholinesterase pada Petani di Desa Gajah Pokki Kabupaten Simalungun

\begin{tabular}{ccccccccc}
\hline & \multicolumn{9}{c}{ Penurunan Kadar Cholinesterase } & & \multirow{2}{*}{ p-value } \\
\cline { 2 - 7 } Kebiasaan merokok & \multicolumn{9}{c}{ Tidak normal } & Normal & \multicolumn{2}{c}{ Total } & \\
\cline { 2 - 7 } & $\mathrm{N}$ & $\%$ & $\mathrm{~F}$ & $\%$ & $\mathrm{~F}$ & $\%$ & \\
\hline Tidak & 3 & 2,8 & 5 & 5,2 & 8 & 8,0 & \multirow{2}{*}{1,000} \\
Ya & 4 & 4,2 & 8 & 7,8 & 12 & 12,0 & \\
\hline & 7 & 7,0 & 13 & 13,0 & 20 & 20,0 & \\
\hline
\end{tabular}

Berdasarkan tabel 3 menunjukkan bahwa ada responden yang kebiasaan merokok terjadi penurunan kadar cholinesterase dan ada yang tidak merokok tetapi terjadi penurunan cholinesterase. Hasil uji statistik diperoleh nilai p-value $=1,000$ maka tidak terdapat hubungan yang bermakna antara kebiasaan merokok dengan penurunan kadar cholinesterase pada petani di Desa Gajah Pokki.

Tabel 4 Hubungan Menyirih dengan Penurunan Kadar Cholinesterase pada Petani di Desa Gajah Pokki Kabupaten Simalungun

\begin{tabular}{|c|c|c|c|c|c|c|c|}
\hline \multirow{3}{*}{ Menyirih } & \multicolumn{6}{|c|}{ Penurunan Kadar Cholinesterase } & \multirow{3}{*}{ p-value } \\
\hline & \multicolumn{2}{|c|}{$\begin{array}{c}\text { Tidak } \\
\text { normal }\end{array}$} & \multicolumn{2}{|c|}{ Normal } & \multicolumn{2}{|c|}{ Total } & \\
\hline & $\mathrm{F}$ & $\%$ & $\mathrm{~F}$ & $\%$ & $\mathrm{~F}$ & $\%$ & \\
\hline Tidak & 4 & 3,5 & 6 & 6,5 & 10 & 10,0 & \multirow{2}{*}{1,000} \\
\hline \multirow[t]{2}{*}{$\mathrm{Ya}$} & 3 & 3,5 & 7 & 6,5 & 10 & 10,0 & \\
\hline & 7 & 7,0 & 13 & 13,0 & 20 & 20,0 & \\
\hline
\end{tabular}

Berdasarkan tabel 4 menunjukkan bahwa ada responden yang menyirih tidak terjadi penurunan kadar cholinesterase, dan ada yang tidak menyirih namun terjadi penurunan kadar cholinesterase. Hasil uji statistik diperoleh nilai p-value $=1,000$ maka tidak terdapat hubungan yang bermakna antara konsumsi sirih/suntil dengan penurunan kadar cholinesterase pada petani di Desa Gajah Pokki. 
Tabel 4 Hubungan lama Kerja dengan Penurunan Kadar Cholinesterase pada Petani di Desa Gajah Pokki Kabupaten Simalungun

\begin{tabular}{ccccccccc}
\hline & \multicolumn{9}{c}{ Penurunan Kadar Cholinesterase } & \\
\cline { 2 - 7 } Lama Bekerja & \multicolumn{9}{c}{ Tidak normal } & Normal & \multicolumn{2}{c}{ Total } & p- value \\
\cline { 2 - 7 } & & F & \% & F & \% & F & \% & \\
\hline 10 & 0 & 1,4 & 4 & 2,6 & 4 & 4,0 & \multirow{2}{*}{2,49} \\
$>10$ & 7 & 5,6 & 9 & 10,4 & 16 & 16,0 & \\
\hline & 7 & 7,0 & 13 & 13,0 & 20 & 20,0 &
\end{tabular}

Berdasarkan tabel 4 menunjukkan bahwa tidak ada responden yang bekerja $<10$ tahun, namun ada responden yang bekerja $\geq 10$ tahun. Hasil uji statistik diperoleh nilai p-value $=2,49$ maka dapat disimpulkan bahwa tidak ada hubungan yang bermakna antara lama bekerja dengan penurunan kadar cholinesterase pada petani di Desa Gajah Pokki.

\section{Pembahasan}

Hubungan Kebiasaan Merokok dengan Penurunan Kadar Cholinesterase pada Petani di Desa Gajah Pokki Kabupaten Simalungun

Hasil uji statistik diperoleh statistik diperoleh nilai p-value $=1,000$ sehingga tidak terdapat hubungan yang bermakna antara kebiasaan merokok dengan penurunan kadar cholinesterase pada petani di Desa Gajah Pokki.

Pemaparan pestisida pada petani dapat menyebabkan penurunan aktivitas cholinesterase. Adapun penyebab terjadinya penurunan aktivitas kadar cholinesterase yaitu akibat masuknya zat kimia pestisida ke dalam tubuh melalui oral.

Pestisida dapat menyebabkan peradangan pada tubuh dan bahan kimia pestisida secara langsung meracuni otot jantung atau stroke apabila sudah keracunan berkepanjangan dan kronis.

Menurut hasil penelitian sulaiman, dkk (2017) berdasarkan analisis dan wawancara di Desa Hamparan Perak terdapat permasalahan serius pada lansia saat ini adalah stroke, stroke disebabkan kebiasaan merokok yag berkepanjangan dan tidak rutin untuk mencek kesehatan ke fasilitas kesehatan.

Sejalan dengan hasil penelitian Rahmawati, dkk (2014) menyatakan bahwa hasil uji Fisher's diperoleh p-value $=1,000$ maka dapat disimpulkan bahwa tidak ada hubungan antara status perokok dengan kadar cholinesterase pada petani penyemprot di Desa Sumberejo Kecamatan Balong Kabupaten Ponorogo.

Menurut hasil observasi dilapangan bahwa kebiasaan petani di Desa Gajah Pokki adalah merokok sebelum bekerja dan sesudah bekerja. Namun setelah petani merokok, mereka minum air putih dan minum susu yang dibawa dari rumah selain itu sebelum petani merokok, mereka mencuci tangan terlebih dahulu kemudian petani lanjut merokok. Sehingga dalam kegiatan ini tidak ada dugaan terjadinya penurunan kadar cholinesterase pada petani 


\section{Hubungan Menyirih dengan Penurunan Kadar Cholinesterase pada Petani di Desa Gajah Pokki Kabupaten Simalungun}

Hasil uji statistik diperoleh nilai p-value $=1,000$ maka tidak terdapat hubungan yang bermakna antara konsumsi sirih/suntil dengan penurunan kadar cholinesterase pada petani di Desa Gajah Pokki.

Menyirih merupakan kegiatan mengunyah makanan jenis sirih melalui oral yang sering dilakukan di Desa Gajah Pokki. Para petani hampir setiap hari membawa sirih/ suntil ke tempat kerja. Setelah melakukan penyemprotan pestisida ke tanaman mereka biasanya makan sirih.

Namun pada saat penyemprotan petani tidak menggunakan masker dan sarung tangan dikarenakan petani merasa terganggu saat bekerja. Tetapi hal ini dapat mempengaruhi kesehatan petani.

Sejalan dengan penelitian Wicaksono, dkk (2016) hasil uji statistik diperoleh pvalue= 0,145 menunjukkan tidak ada hubungan antara keadaan kesehatan dengan kadar cholinesterase.

Berdasarkan hasil observasi penelitian dilapangan para petani sebagian besar tidak menggunakan penutup mulut dan sarung tangan, tetapi petani sudah menjaga kebersihan diri sebelum makan, minum dan konsumsi sirih/suntil seperti mencuci tangan dengan air yang mengalir dan memakai sabun. Sehingga tidak terjadi paparan pestisida.

\section{Hubungan lama Kerja dengan Penurunan Kadar Cholinesterase pada Petani di Desa Gajah Pokki Kabupaten Simalungun}

Hasil uji statistik diperoleh nilai p-value $=2,49$ maka dapat disimpulkan bahwa ada hubungan yang bermakna antara lama bekerja dengan penurunan kadar cholinesterase pada petani di Desa Gajah Pokki.

Lama bekerja merupakan lamanya petani saat melakukan penyemprotan tanaman dan menggunakan pestisida di ladang. Lama waktu dalam bekerja pada saat menyemprot dapat mempengaruhi lama pajanan yang menahun ataupun sampai kronis.

Penelitian ini tidak sejalan dengan Istianah, dkk (2016) menyatakan hasil analisis statistik dengan menggunakan uji Chi-square $(p$-value $=0,049)$ bahwa ada hubungan antara masa kerja sebagai petani penyemprot dengan kejadian keracunan pada petani.

Kemudian penelitian ini bertentangan dengan penelitian samosir, dkk (2017) Hasil dari analisis uji chi-square diperoleh nilai signifikasi sebesar 0,036 yang berarti $p<0,05$, maka ada hubungan antara masa kerja dengan gangguan keseimbangan tubuh petani hortikultura di desa Sumberejo Kecamatan Ngablak Magelang. Maka dari hasil tersebut dapat dikatakan bahwa petani yang masa kerjanya $>15$ tahun mempunyai peluang berisiko lebih dari 2,3 kali untuk mengalami gangguan keseimbangan dibandingkan dengan petani yang masa kerjanya $<15$ tahun.

Penggunaan pestisida dapat mengontaminasi penggunaannya secara langsung sehingga dapat mengakibatkan keracunan. Keracunan dikelompokkan menjadi 3 bagian yaitu keracunan ringan, keracunan akut berat, dan keracunan kronis. Keracunan kronis merupakan keracunan yang penggunaan pestisida dengan waktu yang lama sehingga menimbulkan dampak kesehatan pada manusia (Djojosumarto, 2016).

Berdasarkan asumsi peneliti bahwa petani yang sudah lama tinggal menetap dari kecil sampai berkeluarga di Desa Gajah Pokki, bekerja rata-rata > 10 tahun tetapi sebagian besar petani bekerja sudah memakai alat pelindung diri seperti penutup kepala, baju kerja, sepatu bot, dan sarung tangan. Sehingga apabila petani sudah lama bekerja mencapai $>10$ tahun, tetapi memakai alat pelindung diri dapat mengurangi masuknya racun kedalam tubuh petani.

Berdasarkan hasil observasi yang dilakukan peneliti dilapangan bahwa petani yang berada di Desa Gajah Pokki ada beberapa petani yang mengalami penurunan kadar cholinesterase dikarenakan Petani bekerja > 10 tahun tetapi petani mengakui para petani sudah 
menggunakan alat pelindung diri walaupun belum lengkap, namun hal ini sudah dapat mencegah masuknya zat/kimia ke dalam tubuh.

Pada saat pemeriksaan awal ditemukan bahwa 2 orang mengalami penurunan kadar cholinesterase hal tersebut dapat dilihat dari kebiasaan merokok dan berkurangnya pola makan yang baik.

Pola makan yang baik akan mempengaruhi kebugaran tubuh saat bekerja. Pola makan yang baik dan seimbang dulunya sering disebut 4 sehat 5 sempurna. Ini adalah anjuran yang sangat hakiki bagi semua orang terutama pada petani. Indonesia pada dasarnya bermata pencaharian sebagai seorang petani dikarenakan Indonesia adalah negara agraris begitu juga dengan kabupaten Simalungun petani di Desa Gajah Pokki. Sehingga petani harus menkonsumsi nutrisi yang baik untuk menjaga kesehatan petani. Menkonsumsi makanan pokok yang lengkap salah satunya adalah beras, jagung, umbi-umbian, lauk-pauk, sayur-sayuran dan ditambah susu (BPS, 2010).

Tetapi kebanyakan petani di Desa Gajah Pokki mengakui tidak terlalu menyukai air putih melainkan mereka lebih sering meminum kopi di warung setelah bekerja. Untuk itu apabila petani lebih memilih menkonsumsi kopi maka nutrisi yang di dapat lebih sedikit dibandingkan petani yang lebih sering memilih konsumsi air putih dan susu, akan membantu menetralisirkan racun pestisida di dalam tubuh dan obat pestisida tidak melekat di dalam tubuh petani seutuhnya. Sehingga dapat mencegah terjadinya penurunan kadar cholinesterase.

\section{Kesimpulan}

1. Tidak terdapat hubungan yang bermakna antara kebiasaan merokok dengan penurunan kadar cholinesterase pada petani di Desa Gajah Pokki.

2. Tidak terdapat hubungan yang bermakna antara menyirih dengan penurunan kadar cholinesterase pada petani di Desa Gajah Pokki.

3. Ada hubungan yang bermakna antara lama bekerja dengan penurunan kadar cholinesterase pada petani di Desa Gajah Pokki.

\section{Saran}

1. Bagi Intitusi Terkait Puskesmas, dan Dinas Pertanian sebaiknya lebih memperhatikan kesehatan petani dengan melakukan pemeriksaan racun dalam petani dan menggunakan bahan pestisida yang aman pada petani.

2. Bagi petani/ masyarakat sebaiknya mengaplikasikan pestisida harus sesuai dengan aturan pemakaian yang ada di kemasan obat pestisida, dimana yang perlu diperhatikan cara atau metode aplikasi, kebersihan diri seperti cuci tangan dengan sabun hingga bersih, segera mandi dan ganti pakaian baju kerja dengan pakaian sehari-hari, apabila tempat kerja jauh dari rumah sediakan pakaian bersih dan langsung diganti pakaian, mencuci pakaian secara terpisah, kemudian makan, minum setelah mandi dan mencuci tangan. Mencuci alat secara terpisah dengan disemprot kan air bersih, menggunakan alat pelindung diri sebelum dan sesudah mengaplikasikan pesitisida, sehingga dapat menghindari kontak langsung dengan bahaya kimiawi dari pestisida.

3. Bagi peneliti selanjutnya diharapkan untuk mencari tahu penyebab dari adanya petani yang mengalami penurunan cholinesterase di Desa Gajah Pokki Kecamatan Purba Kabupaten Simalungun. 


\section{Referensi}

Azwar, Saifuddin. 2010. Metode Penelitian. Yogyakarta : Pustaka Pelajar.

Istianah. DKK. 2015. Hubungan Masa Kerja, Lama Menyemprot, Jenis Pestisida, Penggunaan Alat PelindungDiri (APD) dan Pengelolaan Pestisida dengan Kejadian Keracunan pada Petani di Brebes. Universitas Negeri Semarang

Luknis, Sutanto. 2014. Statistik Kesehatan. Edisi ke- 1, Cetakan ke- 7 Jakarta: Rajawali Pers

Maria. DKK. 2013. Analisa Resiko Pajanan Pestisida terhadap Kesehatan Petani Melon di Desa Curut Kecamatan Penawangan Kabupaten Grobogan. Universitas Diponegoro

Rahmawati. DKK. 2013. Pengaruh Faktor Karakteristik Petani dan Metode Penyemprotan terhadap Kadar Cholinesterase di Desa Sumberejo Kecamatan Balong Kabupaten Ponorogo

Samosir. DKK. 2017. Hubungan Pajanan Pestisida dengan Gangguan Keseimbangan Tubuh Petani Hortikultura di Kecamatan Ngablak Kabupaten Magelang. Universitas Diponegoro.

Sastrawijaya,A.T. 2013. Pencemaran Lingkungan. Jakarta : Rineka Cipta.

Sastroasmoro, Prof. Dr. Sudigdo dan Ismail, Prof. Dr. Sofyan. 2011. Dasar-dasar Metodologi Penelitian Edisi ke-4. Jakarta : Sagung Seto

Sugiyono. 2011. Metode Penelitian Kuantitatif, Kualitatif dan R \& D. Bandung: UPI PRESS

Sulaiman, Anggriani Anggriani. 2017. Sosialisasi Pencegahan Kasus Stroke pada Lanjut Usia di Desa Hamparan Perak . Jurnal Amaliah. Vol 1 No. 2

Wicaksono. DKK. 2016. Faktor Internal yang Berhubungan dengan Kadar Cholinesterase pada Darah Petani Kentang di Gapoktan Al-Farruq Desa Patak Banteng Kecamatan Kejajar Kabupaten Wonosobo

Yuantari. DKK. 2013. Tingkat Pengetahuan Petani dalam Menggunakan Pestisida (Studi Kasus di Desa Curut Kecamatan Penawangan Kabupaten Grobogan). Universitas Diponegoro Semarang Indonesia 